\title{
THE EMINENCE OF POETIC ARABIC LANGUAGE: LAMIYYAT AL ARAB OF ASH-SHANFARA EXAMPLE
}

Yahya Saleh Hasan Dahami Al Hababi ${ }^{1}$

${ }^{1}$ Associate Professor, English Department - Faculty of Science and Arts

AL BAHA UNIVERSITY

Al Baha - KSA

ORCID: https://orcid.org/0000-0003-0195-7878

\begin{abstract}
*Corresponding Author: Yahya Saleh Hasan Dahami Al Hababi
${ }^{1}$ Corresponding Author Email: dahami02@gmail.com, ydahami@bu.edu.sa

Article Received: 04-01-20 Accepted: 25-02-20 Published: 05-03-20

Licensing Details: Author retains the right of this article. The article is distributed under the terms of the Creative Commons Attribution-NonCommercial 4.0 License

(http://www.creativecommons.org/licences/by-nc/4.0/) which permits non-commercial use, reproduction and distribution of the work without further permission provided the original work is attributed as specified on the Journal open access page.
\end{abstract}

\section{ABSTRACT}

The significance of the Arabic language holds back from its being one of the most explicit languages in its brilliance and its repeated ability to adapt to countless other sciences and knowledge. The Arabic language has reached creativity and originality in different fields of literature in which the greatest is poetry.

The paper aims at scrutinizing the figurative, rhetorical and aesthetic images in Lamiyyat Al Arab by Ash-Shanfara in which it follows the deductive, inductive critical approach focusing analytically on the first ten verses of the poem. Applying the historical-analytical method, the study attempts to reveal in the in-depth analysis of the aesthetic qualities and poetic issues as well as the figurative images in the poem. It commences with an introduction on Arabia and Poetic Language then moves to shed light on the protagonist-poet Ash-Shanfara as a great Arabic poet to be concluded with analysis and comments on the poem Lamiyyat Al-Arab trying to find out the original Arab values, morals, ethics, and tenets in the pre-Islam era it contains.

Keywords: Arabia, Arabic-language, Arabic-poetry, Brigand, Pre-Islam

\section{INTRODUCTION}

\section{Arabia and Poetic Language}

The Arabic language has been exposed to these alternatives, like all other existing languages, and fluctuated and swung on a number of conditions, so its expressions and verses varied via 
sculpture, substitution and subtraction, and many foreign words became part of it in different ages before being codified and formed in times not realized by antiquity. However, critics learn and get evidence from realizing words enunciation and connotation. Arabic is characterized by accuracy in terms of words and their structures. However, in the Arabic language, poetry "is full of music and exquisite accent ... With its perpetual relying on sound and connotation, poetry plays an essential part. As the great modern Arab poets have often advocated, poetry may have a chief attitude on the transformations arising in cultures, societies and civilizations" (Dahami, 2018a).

Nowadays, the Islamic historians are and were primarily "interested in the Koran, poetry and genealogy, they have described two main features in pre-Islamic history: the first, the city of Mecca and its sacred shrine, the Ka'bah; the second, the life of the nomads" (Faris, 1946: 43) through the setting of the arid but imaginative land as its scenery and with the varied recurrence "of minor raids and fights for the possession of a well or the revenge of a murdered kinsman. Undoubtedly, Mecca was an important center in Arabia, and Bedouin life was the most characteristic feature of the pre-Islamic age" (Faris, 1946: 43). Yet those who promote Arab customs and make the most considerable practice of the Arabic language are in various instances "no longer Arabs themselves; few of the legalists, philosophers, historians, poets, storytellers who adorned the Court of Baghdad and made the Arabic language one of the most prolific in literature in the world could boast the blood of Arabia" (Coke, 1929: 77). Furthermore, "The Arabic language is presented as the perfection and excellence of phraseology and full with flashes of humor and pageantry" (Dahami, 2018b). According to critics, "The Arab mind ... is clear and positive, and the Arabic language nervous, virile, and rich both actually and potentially. The old Arabs were acute and observant people" (Thorndike, 1927: 285).

Tribes of Arabs used to hold a manner of dominance, proven in Tihameh and Al Hejaz, the area of Mecca and Medina, as well as likewise in Nejd or what is called "the high land of central Arabia, at the time when the earliest extant Arabic literature was produced. There can be no doubt that these spoke with all the grammatical inflections. The poetry of the period is a sufficient proof" (Chenery, 1869, p. 12). Likewise, "so far as we can tell, Mecca made a nearer approach to the contemporary standard of civilized life than any other settlement in peninsular Arabia" (Hogarth, 1922: 17).

Arab literature influenced world literature in many different areas of literature, particularly poetry and novel. The Utmost influence and inspiration "was in the tales of The Arabian Nights and it influenced different eras of the English literature. The Orientalists contributed to transfer the Arab Culture to Europe via translation of the Arab literature to their languages" (Dahami, 2017).

If the reader/critic ponders over the history of each manifestation of Arabic, such as ethics, beliefs, principles, moral values, culture or laws, as it spreads and surpasses through its growth, he might realize the history of Arabic advances unfelt for an extended period, and intersperses with gradual moving and resilient and pliable stability originates by the passage of time to be named resurgence or revival. The reason for such resurgence frequently comes because of the modifications of ideas by the mingling of nations and by migration which is demanded or necessitated sometimes by nature of scarcity, conflict, struggle, encounter, clash or fear. 
Additionally, it is also the consequence of political or social achievements, and the mingling of the typology, the variety of traditions and ethics, faiths and literature, in which the language is part of all that; it is the protection of the effects of that alterations. Arabic language protected and secured all of that for times after the disappearance of such traditions or ethics. According to As-Safdi, (1305 H.) in his book Al-Ghaith Al Musajam fi Sharh Lamiyyat Al-Ajam, Omar ibn Al Khattab says: teach your offspring Lamiyyat Al Arab, for the reason that it edifies them morals and ethics (p. 13). It is mentioned likewise in Al A'amoudi (2002).

As for its terminologies, critics find in the Arabic tongue special meanings and connotations for each articulated word. Instances of the accuracy of the terminologies easily show various meanings. Every nation has its own miracles in its language, in which many meanings can result from a few words such as the Arabic maxim which says (خير الكلام ما قل ودل) "the elite speech is the direct and concise" (Shaher, 2008: 204). It is a prove of the greatness of the Arabic language. "Arabic language is rich with proverbs, perspicacity, sagacity and wisdom" (Dahami, 2019). The Arabic proverb is also interpreted as 'Good brevity makes sense'. However, the Arabs, who use classical Arabic are better able to do so than others because the language and its connotations help them as well as being accustomed to it. "From the start, therefore, what made Arabs recognizable to one another was not a geographic or an ethnic feature, but a language" (Cachia, 2002: 31). There are many examples in Arabic to make it superior such as its poetic language of many metaphors, images, symbols, similes, signals and other methods of innovation.

\section{Ash-Shanfara, The Poet}

The word Shanfara means the person of two big lips. The poet, Ash-Shanfara, is of Al Azd tribe of Arabia died in 510 A. D. (Al-Adl, 2002: 89). He is one of several runners who were eminent and famous by their nimbleness in the race. Legendary racers among the ancient Arabs were Ash-Shanfara, Amru ibn (son of) Barraka, Taabbata-Sharran, Solaic ibn AlSalaica, and several others. There was no horse that could challenge them in a running race or chase.

Ash-Shanfara flourished undeniably shortly before Prophet Mohamed, for he was contemporaneous with Taabbata-Sharran. As Az-Zamakhshary (1300 Hijri), mentions in the Book of The Best of Wonders in the Interpretation of Lamiyyat Al-Arab, (p. 11), concerning the name of the poet is Ash-Shanfara, ibn Al-Aus, ibn Al-Hujr, ibn Al-Azd, ibn Al-Ghauth, ibn Nabet, ibn Zeid, ibn Kahlan, ibn Saba. However, Al Asfahani (2008), in his Book of AlAghani (The Songs) Vol.21; remarks that Ash-Shanfara is from Al-Aus, ibn Al-Hujr, ibn AlHanu ibn Al-Azd, ibn Al-Ghauth (p. 128). On the other hand, As-Sadowsi (2011), in his book Poetry of Ash-Shanfara Al- Azdi comments on his title saying that Ash-Shanfara is from Banou Al- Harith ibn Rabai'a, ibn Al-Aus, ibn Al-Hujr, ibn Al-Hanu, ibn Al-Azd, ibn AlGauth, ibn Nabet, ibn Zeid, ibn Kahlan, ibn Saba (p. 20).

After killing his father-in-law Abo Al- Joud and as a result of killing his father when he was a child, Ash-Shanfara had avowed to kill a hundred men of Banou Salaman (Banou is an Arabic expression means 'sons of') and he did succeed in achieving his oath and killed ninety-nine men plus one was killed when kicking his skull after the death of Ash-Shanfara. Some of his characteristics are illustrated by Farrin (2011), declaring: "he can take the heat, make decisions on his own, help out in a fight. Although he possesses no camel, he manages 
very well in the trackless wastes without one". On every occasion Ash-Shanfara meets a man from Banou Salaman, he tells him: take it in your side, but he directs his arrow straight to his enemy's eye. As a result, the tribe of Banou Salaman tried to put him in pitfalls, but they could not achieve their goal quickly. One of them told stories about his end saying that Banou Salaman planned to make him fall in pitfalls. As some historians say it, it was Osaid, ibn Jaber, a prominent runner, who detained Ash-Shanfara. He carried on looking for him until Ash-Shanfara descended into a well to drink, and he trapped him by night. Banou Salaman's tribe caused Ash-Shanfara to die; however, after a period of time, one of them went by his skull and having jerked it, a crust of the skull went into his toes, and injured him to be the reason for his death. Thus, Ash-Shanfara accomplished a hundred men he had sworn to take their souls avenging his family and father-in-law.

Ash-Shanfara decided to banish and deport himself from his clan. He is more concerned with the remote beings and creatures of the desert such as foxes, tigers, hyena, and wolves that have become his comrades in calamity; he pledged revenge - but in an honorable way against the disloyalty of his father's tribe, who consistently called attention to his landmarks to all who wanted him, forcing him to go away more in-depth into the depths of the largest desert of Arabia, the desert of ar-Robu'Al-Khali. He commenced taking his intention swearing to kill one hundred from them. However, before doing so completing a hundred men, he was caught via a snare; he died after he had killed ninety-nine men of Banou Salaman. Nonetheless, it was to count without the expression of the versifier who was then the prophetic expression. A procession of his clan came to spend a day near to the place where the residues of the poet were left to the scavengers who disembowel leaving a carcass scattered in disorder in the desert. Laughing at the destiny of our poet, a caravaneer jerked the carcass and took a bone in the plant. The caravaneer died presently fulfilling the promise of slaying a hundred persons.

Ash-Shanfara, from the wide tribe of Azd, a poet as well as a runner, is the center of the proverb, 'the fastest runner' where no one can follow or catch. He was a legendary runner. In this proverb, the Arabic expression $A^{\prime} A D A$, denoting to the runner is taken in a logical meaning derived from the Arabic expression $A$ ' $D W$ which means running. Al-Baghdadi (2006), Mahmoud Shukri Al-Alousi report the adventure that gave birth to this proverb, in his book Achieving Targets in Knowing the Conditions of the Arabs (p. 143). See also Thaif (1960), in his book called History of Arabic Literature: Ignorance Age (p. 375) and AtTurrah: Tawshieh Lamiyyat Al-Af'al le ibn Malik by Ash-Shanqiti (p. 212).

As stated in the book The Story of Literature in Hijaz in the Ignorance Age by Abdul Jabar and Khafaji (1980), once in an unbelievable event took place for Ash-Shanfara and his two comrades. He, Taabbata-Sharran and Amru ibn Barraka found that the people of AshShanfara's clan had ambushed them with several strong men around a well. Moreover, one day when they became at midnight to get water, Taabbata-Sharran told his colleagues that there are indeed some people in ambush, for he hears their hearts pounding. However, the other two said 'we hear nothing'; it might be throbbing of your heart. As soon as he took his hands, he put them on his heart; they said to him at the same time, it does not beat, and he is not able of such weakness. No matter, said his friends, we must unconditionally go to this well and get a drink. Ash-Shanfara came first; the people posted in ambush, having identified 
him, let him get some water to drink. He went to meet his mates and ensured them that the place is empty and there is no one there, and he peacefully drank from the well.

Taabbata-Sharran declares, 'It is not yours that they want' they want me alone.' Amru ibn Barraka went to drink also after Ash-Shanfara; the matter goes the same with him as of the first. Then and there Taabbata-Sharran said to Ash-Shanfara, he will not lean forward to drink, that the hidden people will come over him and take him. He said 'once you see that, be off as if you were escaping, and hiding at the bottom of this bank; and when you hear take, take, come to me, and liberate me. He similarly addressed Amru ibn Barraka: "For you, I will propose to make you a captive of these people voluntarily: do not go far-off from them but do not grieve that they let you masters of your person. After finishing the prepared proposal, Taabbata-Sharran went down to the ambushed well to drink: but the moment he came near water, the concealed people who were in ambush jumped over him and tangled him with a steady string.

Ash-Shanfara fled as was arranged, and remained at the place which Taabbata-Sharran had indicated. For Amru ibn Barraka, he positioned himself in a place in which they can realize him. At that point, Taabbata-Sharran told those who were seizing him, 'People of Badjila, we let you release us on fair terms! In this case, Amru ibn Barraka will surrender to you as a prisoner. They replied with an agreement. 'Woe to you, Amru ibn Barraka', said TaabbataSharran. 'You knew that Ash-Shanfara had fled, and he suffered the fire of Banou Folan. You knew what had happened between your clan and us. Will you surrender then after capturing us they accept ransom?' Amru ibn Barraka, as it was arranged, ran towards the highland and back. As soon as the others thought he was tired, they took the chance to use it, and they began to pursue him. Simultaneously, Taabbata-Sharran shouted, 'take, take'. Then AshShanfara ran to the agreed signal where Taabbata-Sharran was arrested and cut the strong string that bound the prisoner. Amru ibn Barraka seeing him unbound came to meet him, and Taabbata-Sharran began to scream 'people of Badjila! you have appreciated the race of Amru ibn Barraka, I run even better and faster, and in a manner to make you stop thinking about his race. Thus, they escaped and disappeared. Ash-Shanfara and his friend were free (p. 294). See also Al-Mufathaliat by Al-Thabiy (1998: 15).

\section{Lamiyyat Al-Arab (the poem rhymed with $L$ )}

Poetry is the richest and most profound in language and the most moving among the makings and inventions of thought and mind. Poetry alone has the ability to touch the uppermost degree of eloquence, fluency and coherence. It is poetry that is the most attractive ornament of tales and languages. Of all expressions, one might hear that poetry can control itself most with no trouble; it is the work that best divulges the intellect of a man. So, it is Lamiyyat AlArab.

The poem carries the name of Lamiyya since all its rhymes end with a le sound. Lamiyyat Al Arab is composed of sixty-eight verses. The fame of it comes from the deep connotations it comprises. Many of the verses are of what the Arabs boast because it carries most of the decent values and morals that Arabs, ancient as well as today, like to beautify and to reminisce that such values are of their quality. The poem is also considered as one of the essential Arabic language providers. The "Arabs brought with them their immemorial instinct of restlessness. This habit also is apt to persist in a settled society, finding satisfaction in annual recourse to tent or hut life and in annual predatory excursions" (Hogarth, 1915: 24). 
Lamiyyat Al Arab is a long poem that has a fantastic Arabic tale. It is necessary to recapitulate the poem to grasp the significant denotation and prophetic expressions of a revolutionary poet. Ash-Shanfara, having been a road cutter and living with plundering to the disadvantage of the cavalcades, attracted the anger of merchants and intermediaries against his clan.

The Poem, Lamiyyat Al-Arab, is counted as one of the magnificent poems that have led to diverse opinions as a result of the variety of ideas about its composition and influence on the history of Arabs and on Arabic poetry, as well as the elegance it uses in modeling the personality of a free distinguished individual. Lamiyyat Al-Arab is an enlightening deductive poem calling for the ultimate patient tolerance of hunger as it was the dignified and habit of Arabs, preferring death to obtain charity and self-reliance regarding making a living.

It is undoubtedly Lamiyyat Al-Arab that positively counts among the oldest Arab great poems before the spread of Islam in Arabia. It has founded the legends of the courage and the generosity of the combatant traveler who crosses the ages to reach listeners, to move readers with realities and veracities that reality has quickly exposed today. "Endurance, independence, courage, desert savoir-faire, not to mention generosity ... these traits are all fundamental virtues in a Bedouin context" (Farrin, 2011). Difficulties are striking with magnificence and ancient wisdom which recalls the duties and responsibilities of people such as courage and valor, the given word, the sense of dignity, the sense of nobility and duty as it is the nature of Arabs in that time.

Ash-Shanfara and his companions were proud that they were not exposed in their raids and invasions to honorable masters but against the miserly rich. It is a true convention of honor for prevailing culture as it is still available in communities because it has been gotten from a lengthy convention of nearly chivalrous and noble edification. Furthermore, the honor was a virtue of pre-Islamic Arabia. Probity and bounty, Ash-Shanfara stresses that these are the real treasures of man. The only rich being is the honor, open-handed and generous. Moreover, such wealth, he specifies by prophecy and precognitive wisdom, cannot be the cause of impudence and audacity but if this was to be the reason, at that juncture the poet chooses deprivation, starvation, cold, distress and wind which are, according to Ash-Shanfara, the liberal source of creativeness and poetry.

Lamiyyat al-Arab commences with one of the fascinating initial lines in all of Arabic poetry. "Arabic poetry raised a distinctive voice that the reverberated across desert, village and town. Among its functions at religious feasts and commercial fairs was its influence in confirming a common macro culture across the varying micro-cultures of Arabia" (Allen, 2006: 78). With one domineering and explanatory statement, Ash-Shanfara explodes an ethical essence of the familial system. Affiliation loyalty grips together with the clan and close association between two affiliates of the extended family. This attitude is briefly summed up in the Arabic saying, 'I and my brother against my cousin; I and my cousin against the stranger' (Mansour, 1990: 104).

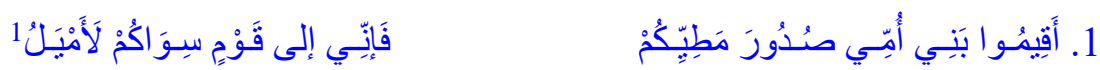

O sons of my mother, Raise the chests of your riding mounts,

\footnotetext{
${ }^{1}$ Hanafi, Abdul Haleem. 2008. Interpretation and Study of Lamiyyat Al-Arab for Ash-Shanfara, Cairo: Maktabat Al Adab. p. 8. [All Arabic verses about Lamiyyat Al-Arab in this study are from this edition of the book, pages 8-11.]
} 
for I incline to a better clan than you

The poet in this first line figuratively forward a command addressing his tribe, clan, and family urging them to be prepared for leaving. However, the intention is to leave alone. Allegorically, in this poem 'Lamiyyatu'l Arab, Al-Shanfara initiates his poem by declaring his intention to travel away from home for reasons of his own, that are explicitly and implicitly stated in various sections of the poem" (Mansour, 2005). An interesting portrait is conceived by realizing that he inquires his brothers being ready for travel but connotatively we comprehend that he travels alone as a result of his intention of deposition of his tribe. Ash-Shanfara drives off, using both with concrete and metaphoric meanings, the very closest of his family relations and states that he decides on a tribe of his own selecting. Paradoxically, he substitutes his clan with another clan of non-human creatures. Furthermore, he puts poetic tradition on its head. The commentary of Az-Zamakhshary on Ash-Shanfara's poem, though wordy and long-winded in respect, that of syntactic analysis, leaves ample aspects to be desired under another poetic aspect. Through the motif of departure, a poet typically begins his verse with an expression of pained unwillingness. He frantically wants his beloved to stay, even though certainly the beloved must go with her clan. Upon grasping the camels moving out, the poet is inclined to let down a waterfall of tears.

Ash-Shanfara reveals no loathness or sadness. Instead, he instructs the riding gathering to leave. He confirms that he is happier after leaving them. Since Ash-Shanfara was an eminent su'luk (brigand), readers/critics can assume that the listeners are well accustomed to his circumstances. In this example, the loathed outcast cracks the tables on the tribe. He rejects them. One can only envisage the jolt this verse sent by early spectators. "Al-Shanfar" describes the scene of imminent leave-taking" (Liebhaber, 2003):

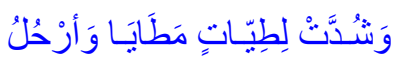

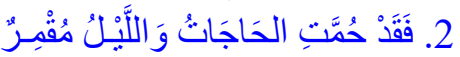

For the provisions are at hand and the night is moonlit,

and mounts have been saddled and stacked for departure.

Liebhaber (2003), states that this is not meaningless leaving without purpose. "The narrator must break from his tribe and is resigned to this painful eventuality. The purpose is clear: the narrator seeks a space free from hypocrisy and blame, where he may reclaim the virtues debased by tribal practice". Concerning the ambiguity of the second verse, one could determine that requirements have been arranged for his trip. The ambiguity is resolved by assigning the provision preparation for the departing. The provisions are ready since the night is moonlit and the mounts fastened and saddled for the trip. The poet's maxim 'The night is moonlit' connote that the matter is clear and unambiguous and no suspicion in it. The meaning here is that the poet tells them 'hurry to leave, the needs are done, the reasons were paved and preparations were made.'

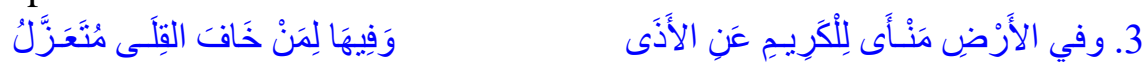

The earth offers shelter for the decent man,

for the one who fears contempt, a place for segregation

Hitherto for the wise brigand the earth provides a refuge. In denoting to a safe area, AshShanfara specifies that obloquy and the likelihood of violent vengeance are restricted to the clannish circle. In this verse, the poet illustrates a great picture of the noble, honorable, virtuous and dignified man, and he distances himself from harm and evil. The poet might inquire why the stay with those who hate you and want to insult you, the land has enough 
capacity for the honor to depart from those who harm them and keep away from those who hate them.

The decent man is a free man who does not accept harm, and if he sees that he shifts from his place to another place. The spirit of such a man is precious and the earth is broad and spacious. If his people abused or insulted him, his response is going away from them; this is what Ash-Shanfara, the owner of this poetic verse said. This verse line has great wisdom in it: its meaning is that the decent man has the ability to evade humiliation by migrating to an inoffensive place far from those who are expected to show humiliation. The situation is the same, according to the poet, that parting of people is better than the endurance of harm.

In this verse line we find an explicit description of the decent man and that individual who does not accept degradation and humiliation, and if he happens to be insulted, his generosity requires him to leave, and that whoever does not leave in revenge for himself is not decent. Here the meaning indicates original connotations that presages existential values related to the behavior of the self. It is a call against surrender and a warning for departure in its

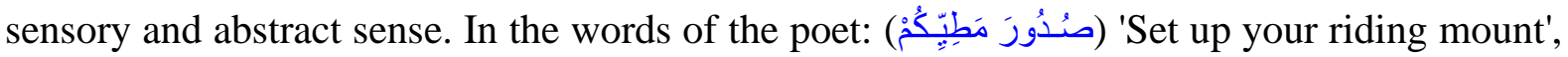
in the first verse line, means to embark on the journey of victory for the injured self and fairness. It is an instant of a turning point in which the poet warns those people who believe in tranquility and passiveness. On the contrary, he is inclined to those people whose nature is traveling searching for dignity and generosity. It is a moment when the heat and warmth rise as in his saying 'provisions are at hand' (حَُّت الحَاجَاتُ) mentioned in the first hemistich of the second verse line of the poem. The poet determines the time of the journey with an appropriate astronomical time; it is the night and the moon in which the capacity of the chest of the earth is too wide for the travelers and the walkers of night.

$$
\text { 4. لَعَمْرُكَكَ مَا بِالأَرْضِ ضِيفقُ على أمرى }
$$

By your age! it does not limit a man

who walked out of dream or fear if he keeps his wits

Society shields barely the amount of the land; outside the social perimeter, in nature, he possibly will find better accommodation. The fourth verse begins with an avow by age and moves at night. The line is confirmation of the previous one that means the land is unrestricted and free for the man pursuing nobility or the afraid who doubts the consequences of hostility. In spite of the sturdy show of defiance at the commencement, Ash-Shanfara reveals an area of private vulnerability in lines 3 The poet intimates that opprobrium from his original clan does move him, and he makes clear that he desires to evade it. After all, AshShanfara is only human. There is on earth an isolated leaving, where the munificent man may be harmless from abuses; a homeless shelter, ready to accept anyone who demands to discharge the abhorrence of his clan.

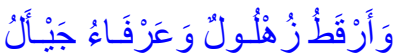

$$
\begin{aligned}
& \text { 5. وَلِي دُونَكُمْ أَهْلُون: سِيـدُ عَتََّسُّ }
\end{aligned}
$$

I have nearer kin than you: a hasty wolf a speckled panther, and a ragged maned hyena

The poet ratifies that he has a better new clan than his previous shameful and dishonorable one. He speaks to the previous addressee describing the new clan in which it is composed of monsters. The poet brings to the screen a personification. He elevates such beasts to a high level, perhaps higher than humans. They are nobler than his previous tribe that he decided to take them off as taking off his clothes. The imagined and symbolic new tribe consists of some 
desert wild animals such as a tiger, a wolf and a hyena but they are not malicious such as the relatives of his previous clan. The other companions of his new lodging will compensate the poet for the loss of his society, a tough wolf in the race, a tiger with short fur like the leopard, and a hyena with a dense mane.

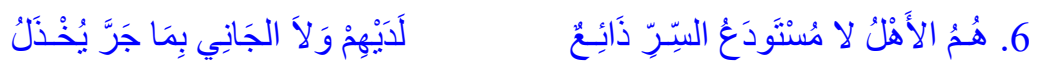

They are the family; none broadcasts a confided secret

Nor the offender for what he has done is forsaken

A metaphorical image is drawn by the poet in this line showing that the beasts are his new family. They are, according to the poet, loyal, faithful, reliable, and trusty. In a company like this, the poet does not panic to see revealing the secret. He, with all the new companions, reject insults; they all combat with gallantry. This verse line is linked to the previous one in which the poet confirms that his new clan (foxes, tigers, hyena, and wolves) are his family. He stresses on the pronoun 'they' in which such creatures are entitled to the name of the tribe or clan. The one who entrusts them a secret they keep it and never reveal. Moreover, whoever commits wrongdoing against any person, they will never submit him and let him down to others because of his offense as his old clan does, so it is a betrayal of his old clan against him. Figuratively, the poet shows an astonishment of the behavior of his old human clan who, according to his views, might not be named a respected, appreciated, or loved clan because they do not keep secret. In addition, they let down, betray and fail their kin. The poet here shows that such a bad clan is not related to Arabs.

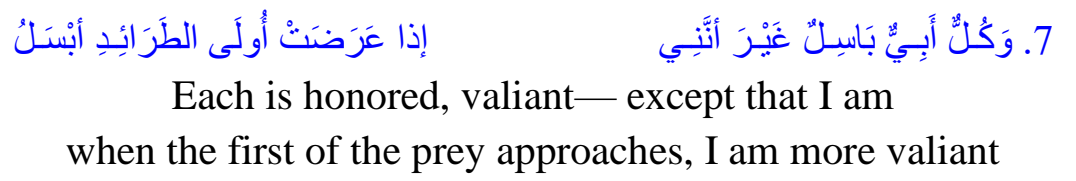

The poet depicts his state indicating that all of what he has mentioned of the new clan are proud, majestic and dignified; they are very severe, austere and unyielding, however; he is tougher, more courageous and of great pride than them. The meaning is that every one of those he mentioned of the family is of a hot nose, not compatible and not binding. They are very severe, but he is even more proud from them. If the first camels that were taken in the raid appeared, and followed by their bosses to save them, he is too speedy and most severe. $\mathrm{He}$ and his new clan are mostly characterized by strength and bravery against their enemies.

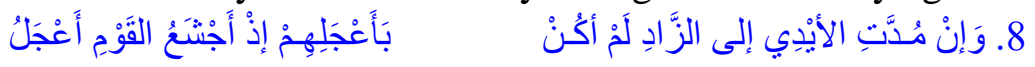

And when hands are extended to eat, mine is not

the fastest, because the greediest is the fastest clan member

Once the matter comes to extending a hand to share nourishment, I do not advance faster because the greediest is the hurried hand-extended. Here we realize one of the values of ancient Arabs which is linked with modesty, decorum and demureness. Ash-Shamri (2012), says that an important aspect of Arabs before Islam is chastity. Chastity in food and eating, for instance, the behavior of Ash-Shanfara where he shows his chaste in eating. Ash-Shanfara believes that greed is in the speed of reaching out to the food, so he rejects such behavior, and refuses to be a slave to food; he is chaste not gluttonous in eating (p. 164).

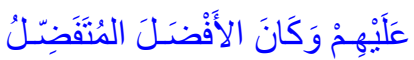

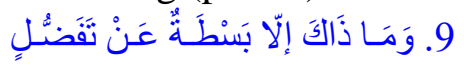

This merely specifies the measure of my kindness

to them; the most righteous is the most virtuous 
It is the outcome of this superiority by which I stand above them: for the first rank belongs by right to the most generous. The meaning here indicates that the poet wants to confirm an Arabic virtue he possesses over his deserted clan. The slowing of his hands-on eating is a reasonable showing that it is his charity to them or an abundance of benevolence to them. He is the most generous. Arabs would call the man if he had a favor for people as generous. The poet says: I have a sense of generosity and that means amplification; it is the amplification of greatness and length. He says: they own and indebted me generosity that I open-handedly bestow them. Amplification here also means his gratitude towards them.

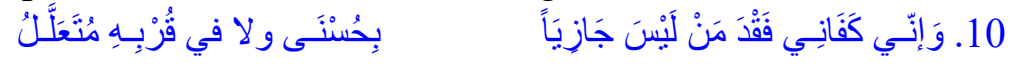

It is enough to me the loss of that who does not repay my favors

and in his closeness, there is no comfort

I bear no difficulty or worries because of the loss of those companions whom the real profits cannot subjugate, and whose neighborhood affords no affable diversion. The poet is amiable because he is relaxed of the concerns and hardship; it is said to the one who is ignorant of any distraction. The poet in the above verse says that he does not show a sort of care for the one who is not equivalent to him or the one does not show good deed. There is no interest in his closeness, no fair in distracting him. He has already lost clans who bear no virtue or value.

\section{CONCLUSION}

The paper intended at scrutinizing inspecting the figurative, metaphorical and aesthetic pictures in Lamiyyat Al Arab. It pursued the deductive method centered on the most significant sources - old and current - and the historical-analytical method for documenting and developing the study attempting to reach authenticity. Lamiyyat Al Arab describes and shows original Arab values and standards in the pre-Islamic period or what is called Al-Jahlia epoch. We might say that it arrived at certain consequences the most significant of which is the influence of Arabic poetic language.

Besides, it is a call of the poet for emigration and transportation to a land of liberty. It deserves the literary perpetuity for the world of Arabic language and poetry. It is rich with proverbs and wisdom. The paper also recommends in profundity examinations in poetic issues and artistic qualities, values and figurative imaginings, taking in mind that Lamiyyat $\mathrm{Al}$ Arab is Ash-Shanfara's poetry. The last expression of our poet, Ash-Shanfara tells that when humanity is corrupt, he must search for virtue but honestly and with dignity. What has been mentioned, might be insufficient to perfectly fulfill the objective of probing the depth of a work like this Lamiyyat Al Arab. It is worthy of further readings and examinations.

\section{References}

Abdul Jabar, A., \& Khafaji, M. A. (1980). The Story of Literature in Hijaz in the Ignorance Age. Cairo: Maktabat Al Kuliat Al-Azhariah.

Al-Adl, H. T. (2002). History of the Literature of Arabic Language, Amman: Dar Osama for Publishing and Distributions.

Al Asfahani, A. F. A. H. (2008). The Book of Al-Aghani ( $3^{\text {rd }}$ Ed.). Beirut: Dar Sader Publishers.

Al A'amoudi, M. M. (2002). Interpretation of Lamiat Al-Ajam (non-Arabs) by Abi Al-Baga Abdullah ibn Al Husien Al A'kbari. Journal of Al Islamiyah University, 10(1), 195244. 
Al-Baghdadi, M. S. A. (2009). Achieving Targets in Knowing the Conditions of the Arabs (Vol. 2), Beirut: Dar Al-Kotob Al Ilmiyah.

Allen, M. (2006). Arab, London and New York: Continuum.

Al-Thabiy, A. M. (1998). Al-Mufathaliat: Selections. Beirut: Dar Al-Argam for Printing, Publishing, and Distribution.

Ash-Shamri, M. M. S. (2012). Dialectical Values in Pre-Islamic Poetry (Ph.D. Thesis). International University of Islamic Sciences, Amman Jordan.

Ash-Shanqiti, H. Z. (n.d.). At-Turrah: Tawshieh Lamiyyat Al-Af'al le ibn Malik. Beirut: Dar Al Kutub Al-Elmiah.

As-Sadowsi, A. F. M. A. (2011). The poetry of Ash-Shanfara Al-Azdi, Verification: Ali Nasir Ghalib, Amman: Dar Al Hamid for Publishing and Distributions.

As-Safdi, 1305 H. (1883). Al-Ghaith Al Musajam fi Sharh Lamiyyat Al Ajam. Part 1. Cairo: Al Azharia Printing Press.

Az-Zamakhshary, M. O., \& Al Mabrad, M. Y. (1300 Hijri). The Book of the Best of Wonders in the Interpretation of Lamiyyat Al-Arab. Cairo: Natharat Al Ma'araif.

Cachia, P. (2002). Arabic Literature: An Overview. London: Routledge Curzon.

Chenery, T. (1869). The Arabic Language: A Lecture. London: Macmillan and Co.

Coke, R. (1929). The Arab's Place in the Sun. London: Thornton Butterworth Ltd.

Dahami, Y. S. (2019). Al-Harith ibn Hillizah: The Ambassador of a Nation. International Journal of Scientific \& Engineering Research, 10(1), 108-116.

Dahami, Y. S. (2018a). The Magnificence of Arabic: Orwa ibn Al-Ward an Epitome, International Journal of English and Literature, 9(7), 79-87. DOI: 10.5897/IJEL2018.1216.

Dahami, Y. S. (2018b). Tarafah ibn Al-A'bd and his Outstanding Arabic Mua'llagah. International Journal of English Literature and Social Sciences (IJELS), 3(6), 939947.

Dahami, Y. S. (2017). James E. Flecker's Poetic Play Hassan: The Arab Influence. Aljouf University Social Sciences Journal (AUSSJ), 3(2), 117-129.

Faris, N. A. (1946). The Arab Heritage. New Jersey: Princeton University Press at Princeton.

Farrin, R. (2011). Abundance from the Desert: Classical Arabic Poetry. Syracuse University Press, ProQuest Ebook Central, retrieved on 2018-09-10 from http://ebookcentral.proquest.com/lib/bahahuniv-ebooks/detail.action?docID=3410085

Hanafi, A. (2008). Interpretation and Study of Lamiyyat Al-Arab for Ash-Shanfara. Cairo: Maktabat Al Adab.

Hogarth, D. G. (1922). Arabia. Oxford: At The Clarendon Press.

Hogarth, D. G. (1915). The Ancient East. New York and London: Henry Holt and Company.

Liebhaber, S. (2003). Al-Shanfara and the Mountain Poem of ibn Khafaja: Some Observation on Patterns of Intertextuality. Journal of Arabic Literature, XXXIV(1-2), 107-121.

Mansour, H. A. (1990). Modern Civilization and Human Relations in Rural Society. Amman: Fathaat for Publishing, Distributions, and Printing.

Mansour, W. (2005). Al-Shanfara's Lamiyyatu'l Arab and The Horrors of Desert Traveling. Ankara Üniversitesi Dil ve Tarih-Coğrafya Fakültesi Dergisi, 45(2), 45-57.

Shaher, J. (2008). Studies in the Artistic Creation in Poetry. Amman: Scientific Yafa House. 
Thaif, S. (1960). History of Arabic Literature: Ignorance Age. Cairo: Dar Al-Ma'arif of Egypt.

Thorndike, L. (1927). A Short History of Civilization. London: John Murray, Albemarle Street, W.

Zaidan, G. (n.d). History of Arabic Language Literature. Part 1. Cairo: Dar Al-Hilal. 